\title{
Unusual infectious agents detected in appendectomy specimens: A retrospective analysis of 42 cases
}

\author{
Kemal Barış Sarıcı $^{1}$ (D), Sami Akbulut ${ }^{1}$ (D), Mehmet Özcan² (D), Khaled Demyati ${ }^{3}$ (D), Emine Şamdancı² (D), Burak Işık (iD) \\ 1 Department of Surgery, Inonu University Faculty of Medicine, Malatya, Turkey \\ ${ }^{2}$ Department of Pathology, Inonu University Faculty of Medicine, Malatya, Turkey \\ ${ }^{3}$ Department of Surgery, An-Najah National University, Nablus, Palestinian Territories
}

\section{ABSTRACT}

Objective: The aim of this study was to evaluate the clinical and histopathological features of 42 patients with unusual infectious agents detected in their appendectomy specimens.

Material and Methods: Between January 1999 and November 2018, 2.754 patients underwent emergency or incidental appendectomy in our clinic, and their pathology reports were retrospectively reviewed. Unusual infectious agents or eosinophilic infiltration of the appendix were reported in the initial pathological examinations of 57 patients. The pathological slides of these patients were re-examined by histopathologists. The examinations revealed that 15 of these patients had no microscopic findings suggestive of parasitic infections. The remaining 42 patients with unusual appendiceal infectious agents were included into the study.

Results: A total of 42 patients ( 25 females and 17 males) aged 18 to 75 years were included into this study. While 32 of these patients (76\%) underwent emergency appendectomy with a presumed diagnosis of acute appendicitis (AAp), the remaining 10 patients underwent incidental appendectomy for various reasons. Twenty-two patients (52.4\%) had histopathological changes consistent with AAp while 20 patients had no evidence of AAp. Histopathological examination revealed infection with Enterobius vermicularis in 38 of the patients, Taenia species in 2, and Ascaris lumbricoides and Actinomyces species in 1 patient each. A total of 24 patients were treated for infections with mebendazole $(n=20)$, albendazole $(n=1)$, niclosamide $(n=2)$, and amoxicillin $(n=1)$.

Conclusion: Unusual infectious agents should be considered as factors potentially triggering AAp, especially in patients living in endemic areas. The appendiceal stump should be inspected for parasite residues.

Keywords: Acute appendicitis, enterobiasis, taeniasis, actinomycosis, ascariasis

Cite this article as: Sarıcı KB, Akbulut S, Özcan M, Demyati K, Şamdancı E, Işık B. Unusual infectious agents detected in appendectomy specimens: a retrospective analysis of 42 cases. Turk J Surg 2020; 36 (3): 291-296.

\section{Corresponding Author}

Sami Akbulut

E-mail: akbulutsami@gmail.com

Received: 07.01 .2020

Accepted: 24.04 .2020

Available Online Date: 28.09 .2020

o Copyright 2020 by Turkish Surgical Society Available online at www.turkjsurg.com

DOI: $10.47717 /$ turkjsurg.2020.4713

\section{INTRODUCTION}

Acute appendicitis (AAp) is one of the most common causes for admission to emergency units due to abdominal pain, and appendectomy is one of the most frequently carried out surgical procedures worldwide. The pathogenesis of AAp is believed to reflect an initial insult to the mucosa, resulting from luminal obstruction, followed by bacterial infection that progressively spreads from the mucosa into the wall of the appendix. It has been previously shown that multiple parasitic diseases can cause AAp in many parts of the world, in particular in underdeveloped countries due to socio-cultural issues and poor hygienic conditions (1-10). The ability of parasites to cause AAp has been debated in the past $(3,4,11)$. Parasites found in the appendix can cause symptoms of AAp, but parasitic infections are rarely the cause of AAp. Herein, we aimed to evaluate the clinical and histopathological features of 42 patients whose appendectomy specimens were compatible with unusual microbial pathogens.

\section{MATERIAL and METHODS}

The primary aim of this study was to share the demographic and histopathological features of patients with unusual microbial pathogens or eosinophilic infiltration in appendectomy specimens. In order to achieve this goal, the pathological reports of patients who underwent appendectomy with a preliminary diagnosis of AAp in the Department of Surgery Inönü University, Faculty of Medicine between January 
1999 and November 2018 were reviewed retrospectively. In the same period, pathological reports of patients who underwent incidental appendectomy for any reason were also reviewed. As a result, pathological reports of 2.754 patients who underwent appendectomy were examined in detail. The pathology slides of 57 patients whose initial pathological examinations had been reported as unusual microbial pathogens or eosinophilic infiltration were re-examined by two histopathologists. The examinations revealed that 15 of these patients had no evidence of any direct or indirect evidence of parasitic infections. Histopathological findings of the remaining 42 patients were consistent with unusual microbial pathogens. The following parameters were examined in this study: age (years), sex (male, female), indication of appendectomy (presumed diagnosis of AAp, incidental appendectomy), appendix width ( $\mathrm{mm})$, appendix length ( $\mathrm{mm})$, histopathological features (AAp, appendix vermiformis, perforated AAp), and unusual histopathological findings (enterobius vermicularis, actinomyces spp., taenia spp.). Ethical approval of the study was obtained from Inonu University institutional review board for non-interventional studies (approval no: 2019/3-3).

\section{RESULTS}

A total of 2.754 patients underwent emergency or incidental appendectomy at our clinic. Of these, 42 patients (1.52\%) had unusual infectious pathogens detected in their appendectomy specimens. Of the 42 patients, aged between 18 and 75 years, 25 were females and 17 were males. The age of the men ranged from 18 to 75 years (mean \pm SD: $34.2 \pm 16.5$, median: 27 years), while the age of the women ranged from 18 to 73 years (mean \pm SD: $32.7 \pm 14.0$, median: 30 years). The lengths of appendectomy specimens ranged from 10 to $90 \mathrm{~mm}$ (mean \pm SD: $59 \pm 20.7$, median: $60 \mathrm{~mm}$ ), while their diameter ranged from 4 to $30 \mathrm{~mm}$ (mean \pm SD: $7.18 \pm 4.8$, median: $6 \mathrm{~mm}$ ).

While 32 patients underwent emergency appendectomy with a presumed diagnosis of $A A p$, the remaining 10 patients underwent incidental appendectomy for various reasons. Histopathologically, 22 patients had inflammatory cell infiltration consistent with AAp in the appendectomy specimens, while 20 patients had no evidence of AAp in their appendectomy specimen. AAp was detected in 21 (65.6\%) patients who underwent emergency appendectomy, whereas AAp was detected in only 1 (10\%) of the patients who underwent incidental appendectomy. Macroscopically, 38 patients had no perforation in the appendectomy specimen, while the remaining 4 patients had perforation in the specimens. Histopathological examination of the appendectomy specimen revealed Enterobius vermicularis (pinworm), in 38 patients (Figure 1); Taenia saginata (tapeworm), in 2 patients (Figure 2); Ascaris lumbricoides (roundworm), in one patient; and Actinomyces spp. in one patient (Figure 3a-b). The main surgical indications in patients who underwent incidental appendecto- my were living donor hepatectomy $(n=5)$, ovarian cyst rupture $(n=2)$, laparoscopic cholecystectomy $(n=1)$, peptic ulcer perforation $(n=1)$, and Amyand's hernia $(n=1)$.

Twenty patients with pinworm infection were given a single dose of mebendazole (100 mg), and the same dose was repeated one week later. Patients with Actinomyces spp. were given oral amoxicillin treatment for four months. Patients with tapeworm infection were administered a single dose (2000 mg) of niclosamide. Patients with roundworms were given a single dose of albendazole (400 mg), and the same dose was repeated three weeks later. Postoperative anthelminthic treatment was not recommended in the remaining patients in line with our clinical approach. None of the patients who did or did not receive postoperative anthelminthic treatment develop any new signs or symptoms indicating parasitic infection during the follow-up period.
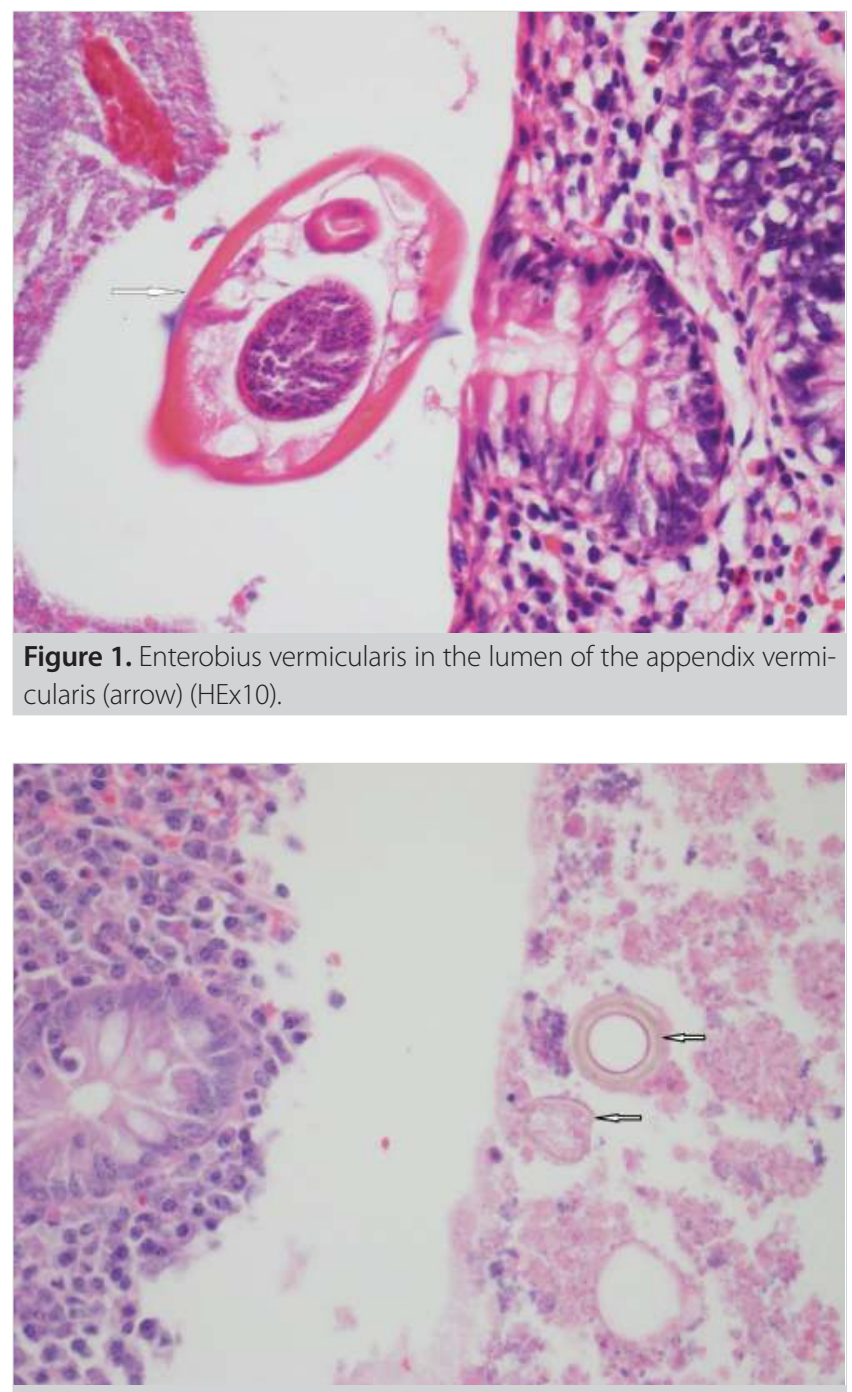

Figure 2. Taenia saginata in the lumen of the appendix vermicularis (arrows) (HEx10). 


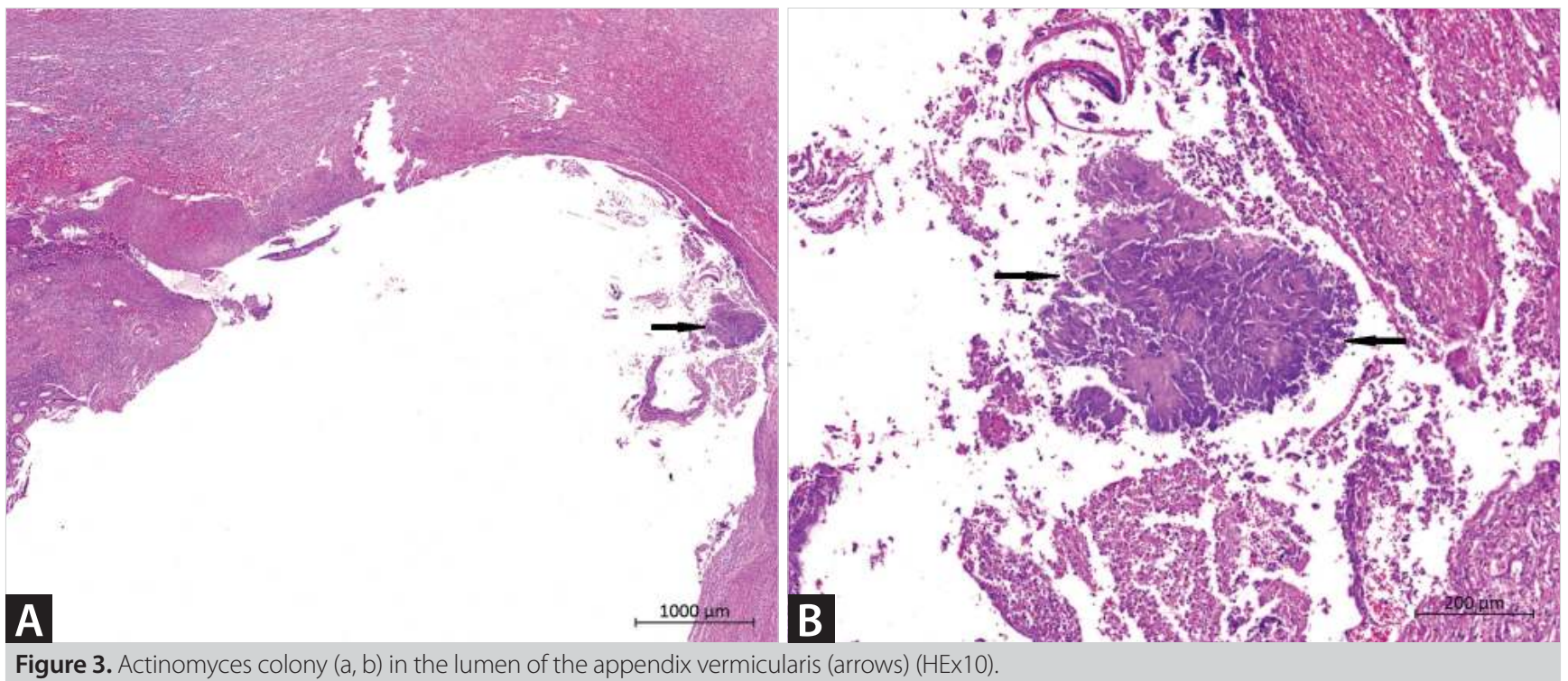

\section{DISCUSSION}

AAp is one of the most common acute surgical emergencies, with an incidence of approximately 100 per 100.000 people $(1,2)$. The incidence varies with different age groups and in different countries, and is lower in populations where a high-fiber diet is consumed $(1,12)$. The pathogenesis of AAp is believed to reflect an initial insult to the mucosa, resulting from luminal obstruction, followed by bacterial infection that progressively spreads from the mucosa into the appendix wall. This luminal obstruction can be caused by fecalith, lymphoid hyperplasia, tumor, or parasites such as pinworms (most commonly), roundworms, tapeworms, or entamoeba histolytica. Inflammation of the appendiceal wall leads to ischemia, necrosis, and eventually perforation, which can result in a localized abscess, plastron, or generalized peritonitis (13).

AAp is pathologically classified in various studies as catarrhal, suppurative, gangrenous, and perforated, according to the degree of inflammation of the various layers of the appendix vermiformis wall. Catarrhal or focal appendicitis is characterized by the initial stage of the inflammation consisting of neutrophils, while edema and inflammation are limited to the mucosal and submucosal areas. In suppurative AAp, inflammation is characterized by marked edema with or without pus involving all the wall layers. In gangrenous AAp, inflammation is seen in all layers, and there are dilated and congested blood vessels in the serosa with necrosis of appendiceal walls. Perforated AAp is characterized by perforation in the serosa and muscularis propria due to inflammation $(11,13)$.

The ability of parasites to cause AAp has been debated $(3,4,11)$. Parasites found in the appendix can cause clinical symptoms of AAp, but parasitic infection is rarely the cause of true AAp. In the majority of parasitic cases, there is no histological evidence of acute inflammation and a significant proportion of the patients infected with pinworm are asymptomatic (5-7). There is a wide spectrum of pathologic findings, ranging from nonspecific changes to perforated AAp $(3,11)$. With careful pathological examination, helminths and their ova may be identified in appendectomy specimens (3).

Numerous parasitic osrganisms can cause AAp and initiate the clinical symptoms of AAp $(3,8,9,11)$. The most common parasites causing AAp are pinworm, tapeworm, roundworm, and the schistosoma species $(8,9)$. The incidence of parasites in patients who undergo appendectomy due to AAp is between $0.35 \%$ and $12.5 \%$ in different parts of the world, which is known to vary according to the different age groups (children or adults) and geographical regions (2-10). A subset of studies published in Turkey has shown that the prevalence of appendiceal parasites in patients who underwent appendectomy due to AAp ranged from $0.7 \%$ to $3.15 \%(3,9,11,14-16)$.

Enterobiasis, are the most common helminths that affect humans and have a worldwide distribution, including even developed countries (17). This small parasite is predominantly found in pediatric populations, with approximately $4 \%$ to $28 \%$ of children infected (18). Enterobiasis infection is usually asymptomatic; however, children with high parasitic burdens have impairments in physical, intellectual, and cognitive development (18). Pinworms inhabit the cecum and are able to crawl into the lumen of the appendix, leading to clinical manifestations resembling AAp. Zouari et al. (7) have reported that $50 \%$ of pediatric patients with negative appendectomy had pinworm infection. This study suggests that enterobiasis should be considered in children with suspected AAp, and recommends that all appendectomy specimens be examined histopathologically, regardless of whether the specimens are macroscopically normal or 
not (7). Although the prevalence of enterobiasis in appendectomy specimens ranges from $0.2 \%$ to $41.8 \%$, it has been shown to be around $1-2 \%(3,4,9,11,16)$. In the present study, pinworm was detected in the appendectomy specimens of $1.16 \%$ of the patients, which is comparable to the literature.

Taeniasis is characterized by the presence of tapeworms in the lumen of the intestine. Eggs are released when tapeworms shed gravid proglottids into the intestine, which are then shed into stools. Patients with tapeworm infection are usually asymptomatic and often only present after passing a proglottid segment in stool (19). The prevalence of tapeworm in appendectomy specimens ranges from $0.039 \%$ to $0.45 \%$, and according to a large literature analysis, tapeworm has been detected in $0.001 \%$ of patients with AAp $(5,9,16)$. In the present study, tapeworm was detected in appendectomy specimens of $0.072 \%$ of the patients.

Ascariasis is one of the most common helminthic diseases and is seen in the intestines of individuals in tropical and semi-tropical countries $(9,20)$. Ascariasis-associated AAp is a form of wandering ascariasis. Ascariasis can be found in the normal appendix but may also be associated with appendicitis. In a study from India, 11 children have been found to have appendiceal roundworms during surgery for different intestinal complications caused by roundworms, 8 of whom (72.7\%) had roundworms inside their vermiform appendix but not did not suffer from AAp, whereas the remaining three patients (27.2\%) were found to have Ascariasis-associated AAp. The characteristic finding in the ascaris-infested vermiform appendix is that the worm is positioned with its head at the base and its tail at the tip of the appendix (20). In the present study, roundworm was detected in appendectomy specimens of $0.036 \%$ of the patients.

Actinomycosis is a rare chronic infectious bacterial disease caused by Actinomyces subtypes. Actinomycosis species are gram-positive bacteria, which are normal commensals of the oral cavity, gastrointestinal tract, and urogenital tract, but they become pathogenic in the presence of necrotic tissue. The cervicofacial, thoracic, and abdominopelvic regions are the most common sites involved in this type of disease. In abdominal actinomycosis, the most commonly involved site is the ileocecal region, including the appendix (21-23). It has been reported that the prevalence of appendiceal Actinomyces in patients undergoing appendectomy due to AAp ranges from $0.02 \%$ to $0.06 \%(21,22)$. In the present study, Actinomyces species were detected in a single appendectomy specimen $(0.036 \%$ of the patients).

It is not yet clear whether appendectomy is sufficient in patients with parasites detected in their appendectomy specimen, or whether postoperative medical treatment should be given. While the prevalence of intestinal parasitic infections is high, the morbidity and mortality caused by these infections is much lower than expected. They are usually considered an unimportant problem, especially in asymptomatic patients. However, intestinal parasitic infections associated with clinical disease are also well documented. Ascariasis can result in fatal intestinal obstruction, hookworm infections can cause iron deficiency anemia, trichuria causes chronic dysentery and is also associated with rectal prolapse, Amebiasis can result in dysentery and extraintestinal complications, and finally giardiasis is associated with acute diarrhea, steatorrhea, and lactose intolerance.

These complications imply that every patient with parasites detected in the appendectomy specimen should receive medical treatment in the postoperative period. A comprehensive literature review published by Akbulut et al. (9) in 2011 showed that most patients with parasitic, tuberculosis, or actinomyces in appendectomy specimens received medical treatment postoperatively. Based on their experience from review studies, Akbulut et al. (9) stated that patients must receive anthelmintic treatment because appendectomy treats only the consequence and not the cause of the disease. Considering the previous experience in our clinic (3), patients with appendiceal parasitic disease usually receive routine postoperative anthelmintic treatment. However, our clinical approach has changed in recent years. We do not recommend routine postoperative treatment for adult patients who have no other clinical signs or symptoms indicating parasitic disease. We do; however, routinely administer postoperative medical treatment for patients with Actinomyces and tuberculosis infections characterized by chronic granulomatous inflammation.

In summary, parasitic infections should be considered as an underlying factor causing AAp, especially in patients living in underdeveloped countries, poor hygiene conditions, and in close-living areas. Parasitic infections can cause inflammation of the appendix or can imitate AAp clinically. It is recommended that all appendectomy specimens be examined histopathologically, regardless of whether the specimens are macroscopically normal. It is still unclear whether appendectomy is sufficient in these patients or whether postoperative medical treatment should be given.

Ethics Committee Approval: Ethics committee approval was received for this study from İnönü University Health Science Non-interventional Clinical Research Ethical Committee (05.02.2019/2019 3-3).

Peer-review: Externally peer-reviewed.

Author Contributions: Concept - S,A., K,B.S.; Design - S.A.; Supervision S.A., E.Ş., B.I.; Data Collection and/or Processing - K.B.S., M.Ö., E.Ş.; Analysis and Interpretation - S.A., K.D., E.Ş.; Literature Review - K.D., S.A.; Writing Manuscript - S.A.; Critical Reviews - S.A., B.I.

Conflict of Interest: The authors have no conflicts of interest to declare. Financial Disclosure: The authors declared that this study has received no financial support. 


\section{REFERENCES}

1. Ferris M, Quan S, Kaplan BS, Molodecky N, Ball CG, Chernoff GW, et al. The global incidence of appendicitis: a systematic review of population-based studies. Ann Surg 2017; 266:237-41. [CrossRef]

2. Akbulut S, Koc C, Kocaaslan H, Gonultas F, Samdanci E, Yologlu S, et al. Comparison of clinical and histopathological features of patients who underwent incidental or emergency appendectomy. World J Gastrointest Surg 2019; 11: 19-26. [CrossRef]

3. Isik B, Yilmaz M, Karadag N, Kahraman L, Sogutlu G, Yilmaz S, et al. Appendiceal Enterobius vermicularis infestation in adults. Int Surg 2007; 92: 221-5. [CrossRef]

4. Akkapulu N, Abdullazade S. Is Enterobius vermicularis infestation associated with acute appendicitis? Eur J Trauma Emerg Surg 2016; 42: 465-70. [CrossRef]

5. Da Silva DF, da Silva RJ, da Silva MG, Sartorelli AC, Rodrigues MA. Parasitic infection of the appendix as a cause of acute appendicitis. Parasitol Res 2007; 102: 99-102. [CrossRef]

6. Arca MJ, Gates RL, Groner JI, Hammond S, Caniano DA. Clinical manifestations of appendiceal pinworms in children: an institutional experience and a review of the literature. Pediatr Surg Int 2004; 20:372-5. [CrossRef]

7. Zouari M, Louati H, Abid I, Trabelsi F, Ben Dhaou M, Jallouli M, et al. Enterobius vermicularis: a cause of abdominal pain mimicking acute appendicitis in children. A retrospective cohort study. Arch Iran Med. 2018; 21:67-72. [CrossRef]

8. Thanikachalam MP, Kasemsuk Y, Mak JW, Sharifah Emilia TS, Kandasamy P. A study of parasitic infections in the luminal contents and tissue sections of appendix specimens. Trop Biomed 2008; 25: 166-72. [CrossRef]

9. Akbulut S, Tas M, Sogutcu N, Arikanoglu Z, Basbug M, Ulku A, et al. Unusual histopathological findings in appendectomy specimens: a retrospective analysis and literature review. World J Gastroenterol 2011; 17: 1961-70. [CrossRef]

10. Zakaria OM, Zakaria HM, Daoud MY, Al Wadaani H, Al Buali W, AlMohammed $H$, et al. Parasitic infestation in pediatric and adolescent appendicitis: a local experience. Oman Med J 2013;28: 92-6. [CrossRef]

11. Tayfur M, Balci MG. Pathological changes in appendectomy specimens including the role of parasites: a retrospective study of $2400 \mathrm{ca}$ ses of acute appendicitis. Niger J Clin Pract 2019;22:270-5. [CrossRef]
12. Almstrom M, Svensson JF, Svenningsson A, Hagel E, Wester T. Population-based cohort study on the epidemiology of acute appendicitis in children in Sweden in 1987-2013. BJS Open 2018; 2: 142-50. [CrossRef]

13. Bhangu A, Søreide K, Di Saverio S, Assarsson JH, Drake FT. Acute appendicitis: modern understanding of pathogenesis, diagnosis, and management. Lancet 2015; 386: 1278-87. [CrossRef]

14. Aydin O. Incidental parasitic infestations in surgically removed appendices: a retrospective analysis. Diagn Pathol 2007; 2: 16. [CrossRef]

15. Yilmaz M, Akbulut S, Kutluturk K, Sahin N, Arabaci E, Ara C, et al. Unusual histopathological findings in appendectomy specimens from patients with suspected acute appendicitis. World J Gastroenterol 2013; 19: 4015-22. [CrossRef]

16. Altun E, Avci V, Azatcam M. Parasitic infestation in appendicitis. A retrospective analysis of 660 patients and brief literature review. Saudi Med J 2017; 38: 314-8. [CrossRef]

17. Bethony J, Brooker S, Albonico M, Geiger SM, Loukas A, Diemert D, et al. Soil-transmitted helminth infections: ascariasis, trichuriasis, and hookworm. Lancet 2006; 367: 1521-32. [CrossRef]

18. Li HM, Zhou CH, Li ZS, Deng ZH, Ruan CW, Zhang QM, et al. Risk factors for Enterobius vermicularis infection in children in Gaozhou, Guangdong, China. Infect Dis Poverty 2015; 4: 28. [CrossRef]

19. Jourdan PM, Lamberton PHL, Fenwick A, Addiss DG. Soil-transmitted helminth infections. Lancet 2018; 391: 252-65. [CrossRef]

20. Wani I, Maqbool M, Amin A, Shah F, Keema A, Singh J, et al. Appendiceal ascariasis in children. Ann Saudi Med 2010; 30:63-6. [CrossRef]

21. Gómez-Torres GA, Ortega-Gárcia OS, Gutierrez-López EG, CarballidoMurguía CA, Flores-Rios JA, López-Lizarraga CR, et al. A rare case of subacute appendicitis, actinomycosis as the final pathology reports: a case report and literature review. Int I Surg Case Rep 2017; 36: 46-9. [CrossRef]

22. Karakus E, Mambet E, Azili MN, Gulhan B, Tiryaki T, Tezer H. Actinomycosis of the appendix in childhood-an unusual cause of appendicitis. APSP J Case Rep 2014; 5: 26. [CrossRef]

23. Lee SY, Kwon HJ, Cho JH, Oh JY, Nam KJ, Lee JH, et al. Actinomycosis of the appendix mimicking appendiceal tumor: a case report. World J Gastroenterol 2010; 16: 395-7. [CrossRef] 


\title{
ORIJINAL ÇALIŞMA-ÖZET
}

Turk J Surg 2020; 36 (3): 291-296

\section{Apendektomi spesimeninde tespit edilen sıra dışı enfeksiyon ajanları: 42 olgunun retrospektif analizi}

\author{
Kemal Barış Sarıcı ${ }^{1}$, Sami Akbulut ${ }^{1}$, Mehmet Özcan² ${ }^{2}$, Khaled Demyati ${ }^{3}$ Emine Şamdancı ${ }^{2}$, Burak Işık \\ ${ }^{1}$ Inönü Üniversitesi Tıp Fakültesi, Cerrahi Anabilim Dalı, Malatya, Türkiye \\ 2 Inönü Üniversitesi Tıp Fakültesi, Patoloji Anabilim Dalı, Malatya, Turkey \\ ${ }^{3}$ An-Najah National Üniversitesi, Cerrahi Anabilim Dalı, Nablus, Filisitin Bölgesi
}

\section{ÖZET}

Giriş ve Amaç: Bu çalışmanın amacı, apendektomi spesimeninde sıra dışı enfeksiyon ajanları tespit edilen 42 hastanın klinik ve histopatolojik özelliklerini değerlendirmektir.

Gereç ve Yöntem: Ocak 1999 ve Kasım 2018 arasında kliniğimizde acil veya insidental apendektomi yapılan 2.754 hastanın patoloji raporları retrospektif olarak incelendi. Elli yedi hastanın ilk patolojik değerlendirmesinde sıra dışı enfeksiyon ajanları veya eozinofilik infiltrasyonun rapor edildiği bulundu. Bu hastaların patoloji preparatları histopatologlar tarafından yeniden incelendi. Yeniden değerlendirme sonucunda hastaların $15^{\prime}$ inde sıra dışı enfeksiyon ajanlarını düşündüren herhangi bir mikroskobik bulgu tespit edilmedi. Sıra dışı apendiceal enfeksiyon ajanları saptanan 42 hasta çalışmaya dahil edildi.

Bulgular: Yaşları 18 ila 75 yıl arasında değișen toplam 42 hasta (25 kadın ve 17 erkek) bu çalışmaya dahil edildi. Bu hastaların 32 (\%76)'sine akut apandisit ön tanısıyla acil apendektomi yapılırken geriye kalan 10 hastaya çeşitli sebeplerden dolayı insidental apendektomi yapıldı. Yirmi iki hastada $(\% 52,4)$ akut apandisit ile uyumlu histopatolojik değişiklikler bulunurken 20 hastada akut apandisit bulgusu yoktu. Histopatolojik incelemede 38 hastada Enterobius vermicularis, ikisinde Taenia türü, birinde Ascaris türü ve bir hastada Actinomyces türü saptandı. Toplam 24 hastaya mebendazol $(n=20)$, albendazol $(n=1)$, niklosamid $(n=2)$ ve amoksisilin $(n=1)$ tedavisi verildi.

Sonuç: Özellikle endemik bölgelerde yaşayan hastalarda akut apandisiti tetikleyen faktörler arasında sıra dışı enfeksiyon ajanları düşünülmelidir ve apendiks güdüğü parazit kalıntıları açısından incelenmelidir.

Anahtar Kelimeler: Akut apandisit, enterobiyazis, tenyazis, aktinomikozis, askariyazis

Doi: $10.47717 /$ turkjsurg.2020.4713 